\title{
Література
}

1. Дудікова Л. Сучасні підходи викладання іноземних мов на не філологічних спеціальностях вищих навчальних закладів/ Л. Дудікова [Електронний ресурс].Режим доступу до джерела: http://www.social-science.com.ua/article/1021

2. Пассов Е. И. Культурообразная модель профессиональной подготовки учителя: философия, содержание, реализация // Иностранные языки. - 2002. - № 4. - С. 11-18. 3. Гончарова О. М. Теоретико-методичні основи особистісно орієнтованої системи формування інформативних компетентностей студентів економічних спеціальностей : дис. доктора пед. наук : 13.00.02 / Оксана Миколаївна Гончарова. - Київ, 2007. - 490 с. 4. Finegan E. Language : its structure and use/ Edward Finegan, Niko Besnier. - San Diego - London: Harcourt Brace Jovanovich, 1989. - 546 p. 5. Закір'янова I. А. Формування соціокультурної компетентності у майбутніх вчителів іноземної мови і процесі професійної підготовки: дис... канд.пед.наук / Ірина Аксанівна Закір'янова. Київ, 2006. - 174 с. 6. Балабін В. В. Сучасний американський військовий сленг як проблема перекладу /В. В. Балабін. - К. : Логос, 2002. - 315 с. 7. Василенко Д. В. Військова лексика англійської мови XX - початку XXI століття/Д. В. Василенко. Горлівка : Вид-во ГДПІІМ, 2009. - 220 с. 8. Левченко Т. І. Розвиток освіти та особистості в різних педагогічних системах / Т. І. Левченко. - Вінниця: «Нова Книга», 2002. - 512 c. 9. Пассов Е. И. Культурообразная модель профессиональной подготовки учителя: философия, содержание, реализация/ Е.И. Пассов. // Иностранные языки. - 2002. - № 4. - С. 18-21. 10. Пассов Е. И. Коммуникативное иноязычное образование / Е. И. Пассов. - Липецк, 1998. - 157 с.

\section{РОЗВИТОК ПРОФЕСІЙНОГО МОВЛЕННЯ СТУДЕНТІВ ЯК ЗАСІБ ФОРМУВАННЯ МОВНОЇ ОСОБИСТОСТІ МАЙБУТНЬОГО ВЧИТЕЛЯ}

Махінов В. М. Розвиток професійного мовлення студентів як засіб формування мовної особистості майбутнього вчителя.

Актуальність дослідження обумовлена значущістю підготовки мовної особистості майбутнього вчителя засобами професійного спілкування під час навчання іноземної мови як системи знань, умінь та навичок, що сприяють розвитку соціокультурної компетенції студентів, формуванню світогляду, моралі та поведінки, готують до професійної діяльності.

Ключові слова: мовна особистість, професійне спілкування, соціокультурний компонент змісту навчання, комунікативна компетенція, міжкультурна комунікація, загальноєвропейський освітній простір.

Махинов В. Н. Развитие профессиональной речи студентов как средство формирования языковой личности будущего учителя.

Актуальность исследования обусловлена значимостью подготовки языковой личности будущего учителя средствами профессионального общения при изучении иностранного языка как системы знаний, умений и навыков, которые содействуют развитию социокультурной компетенции студентов, формированию мировоззрения, морали и поведения, готовят к профессиональной деятельности.

Ключевые слова: языковая личность, профессиональное общение, социокультурный компонент содержания обучения, коммуникативная компетенция, межкультурная коммуникация, общеевропейское образовательное пространство. 
Makhinov V. N. Development of professional language of students as means of forming of language personality of future teacher.

Research actuality is conditioned by meaningfulness of preparation of language personality of future teacher by the means of professional intercourse at the studies of foreign language as systems of knowledge, abilities and skills, that assist to development of sociocultural competence of students, forming of world view, moral and behavior, prepare to professional activity.

Key words: language personality, professional communication, sociocultural component of maintenance of studies, communicative competense, cross-cultural communication, European educational space.

Навчання іноземних мов на сучасному етапі розглядається не тільки як педагогічна чи методична проблема, а як створення умов для усвідомлення відмінностей у рідній та іншомовній культурі, виховання толерантного ставлення до представників інших народів, зниження рівня етноцентризму, формування навичок іншомовної міжкультурної комунікації та готовності до діалогу культур. Ураховуючи міжпредметний характер навчального процесу i його педагогічну та соціальнофілософську спрямованість, автор намагався спиратися на всі групи наукового доробку з окресленої тематики.

Метою статті є визначити етапи та процес формування мовної особистості майбутнього вчителя, теоретично обгрунтувати роль та значення професійного спілкування під час навчання іноземної мови як системи знань, умінь та навичок, що сприяють розвитку соціокультурної компетенції студентів, формуванню світогляду, моралі та поведінки, готують до життя в багатокультурному суспільстві.

Соціокультурний компетентнісний підхід в освіті дозволяє розглядати досвід підготовки майбутнього вчителя як систему компетентностей у різних галузях суспільного та духовного життя (I. Гудзик, I. Зимня, О. Лебедєв, В. Луговий, О. Овчарук, О. Пометун, І. Родигіна, Л. Скуратівський, А. Фасоля). Питання формування мовної особистості у вітчизняній психолого-педагогічній літературі передовсім пов'язується із поняттям комунікативної компетенції як знань або здатності до ефективної комунікації (Т. Гончар, Ю. Смельянов, Н. Завіниченко, Т. Кобзар, С. Макаренко, К. Моісеєнко, О. Нещерет, Л. Петровська, О. Попова, Л. Федорова), котра тісно корелює із соціальною компетентністю (Н. Калініна, О. Колеснікова, Л. Лєпіхова, А. Мудрик).

Значної уваги приділяють дослідженню мовленнєвої компетентності у професійній діяльності майбутнього вчителя, яка безпосередньо пов'язана із здійсненням комунікації (Н. Завіниченко, Л. Любчак, С. Макаренко, О. Нещерет, Ю. Паскевська, I. Тяллева, Н. Шевченко, Н. Шацька). Особливої значущості набувають характеристики, котрі забезпечують, з одного боку, засвоєння знань, а 3 другого, - оптимальні шляхи взаємодії в суспільстві. Передумовою розвитку зазначених характеристик $\epsilon$ оптимальний рівень володіння мовою. Мовна i мовленнєва компетентність визначається необхідною умовою здобуття компетентності в усіх сферах життєдіяльності суб'єкта (А. Богуш, О. Залевська, І. Зимня, М. Пентилюк, Л. Скуратівський).

На особливу увагу в цьому контексті заслуговують роботи зарубіжних авторів, зокрема М. Бірама, Ж. Зарат, Г. Нойнера, М. Флемінга, Дж. Вальдеса, Дж. Тріма, С. Мартинеллі, А. Дюссапа, Ф. Каррена, М. Тейлора, Дж. О’Ригана та Дж. Ватермана. Європейські тенденції в освітній галузі проаналізовано в роботах Д. Бартелемі, 
Р. Риба, Ц. Бирзеа, Ж.-М. Леклерка, П. Луізоні, Дж. Річі та Ф. Санз, Д. Каллена.

Основним завданням фахової підготовки мовної особистості майбутнього вчителя засобами професійного спілкування $є$ не стільки засвоєння студентами науково-предметних знань, скільки їх генеза та проектування способів застосування. Мовленнєва діяльність $є$ динамічною системою, у межах якої постійно відбуваються відповідні трансформації. Але не до кінця теоретично обгрунтовано та практично доведено роль та значення професійного спілкування під час навчання іноземної мови як системи знань, умінь та навичок, що сприяють розвитку соціокультурної компетенції студентів, формуванню світогляду, моралі та поведінки, готують до професійного життя.

Засновники теорії спілкування - Л. Виготський, О. Леонтьєв, О. Лурія, Т. Ахутіна (Рябова) та інші - вважають комунікацію різновидом людської діяльності загалом, мовленнєвою діяльністю поряд з трудовою, ігровою, пізнавальною та ін. [2, c. 72]. Л. Виготський i його послідовники вважають, що найважливішими складниками діяльності є:

1) мотив - причина, поштовх до початку мовленнєвої діяльності. Мотиви спілкування можуть бути найрізноманітнішими і стосуватись практично всіх сфер людського життя: фізичної, фізіологічної, інтелектуальної, духовної;

2) мета - усвідомлене уявлення про результат мовленнєвої діяльності, якого необхідно досягти в процесі спілкування. Мета тісно пов'язана 3 мотивом мовленнєвої діяльності й впливає на ії̈ подальший перебіг;

3) дія - здійснення чого-небудь 3 конкретною метою, яка випливає із загальної мети;

4) операція - спосіб здійснення мовленнєвої дії. Операції співвідносні 3 умовами досягнення мети (місцем, часом, оточенням, ситуацією, контекстом, різноманітними внутрішніми та зовнішніми впливами тощо).

Мовленнєва діяльність $є$ динамічною системою, у межах якої постійно відбуваються трансформації: акт мовленнєвої діяльності може втрачати мотив i перетворюватися на дію, яка реалізує іншу діяльність; і навпаки, дія може набути самостійної спонукальної сили й стати актом діяльності; дія може трансформуватись в операцію, почати реалізовувати різноманітні типи мети.

Класифікують мовленнєву діяльність за різними ознаками:

- якісна специфіка (трудову, ігрову, пізнавальну);

- сфера вияву (зовнішню, або матеріальну, внутрішню, або теоретичну);

- результат (конструктивну і деструктивну);

- міра участі творчого начала (творчу, або пошукову, i рутинну, або автоматизовану);

- участь складових найважливіших сфер вияву людини (когнітивну, психічну, психологічну, духовну, фізичну, фізіологічну та ін.).

За цією класифікацією мовленнєва діяльність належить до внутрішньої, творчої, когнітивно-психічної з різною мірою конструктивності. Вона $є$ істинною діяльністю, що зберігає загальну структуру людської діяльності, у якій би формі не здійснювалася. Ця діяльність не може бути вилучена із суспільного процесу. Мовленнєва діяльність як спілкування із застосуванням засобів мовного коду є одним iз виявів знакової діяльності людей і ії основним видом, який логічно й генетично передує решті iï видів. Важливою теоретичною проблемою $\epsilon$ співвідношення мовленнєвої діяльності та діяльності спілкування. Оскільки мовленнєва діяльність це спеціалізоване використання мовлення, то в такому сенсі - це елемент діяльності 
спілкування.

На думку деяких дослідників, теорія мовленнєвої діяльності має два складники: психолінгвістику і комунікативну лінгвістику (теорію мовленнєвої комунікації). Зв'язки між видами комунікації формують рівні комунікації. У навчальному процесі важливе місце належить міжособистісному спілкуванню. Міжособистісне спілкування - комунікація між двома i більше особами, яка спирається на їх психологічний і когнітивний зв'язок, що грунтується на особистісно сформованих засадах [1, с. 17]. Міжособистісне (інтерперсональне) спілкування характеризується кількісною ознакою (наявність 2-3 осіб на противагу спілкуванню в малих та великих мовних групах, а також масовому) та якісною (вона наявна лише в тому разі, коли комуніканти сприймають один одного як неповторних особистостей незалежно від кількості учасників спілкування).

Міжособистісне спілкування має в навчальному процесі такі ознаки:

- неповторність взаємодії в межах комунікативного акту - мовленнєва інтеракція не має аналогів серед інших типів особистісних зв'язків людей у суспільстві;

- незамінність іншими типами зв'язків між студентами - кожна особистість для психологічного комфорту й психічного здоров'я повинна «набрати» певну кількість часу мовленнєвого спілкування;

- взаємозалежність учасників міжособистісного спілкування;

- взаємне з'ясування особистісних стосунків - студенти почувають себе комфортніше, якщо мають можливість поділитися думками, почуттями, враженнями тощо;

- взаємні психологічні орієнтації - «відшліфовування» учасниками міжособистісного спілкування своєї психологічної поведінки, психічного стану тощо; черпання психологічної енергії з різних за тривалістю взаємозв'язків;

- особистісні засади спілкування - урахування вироблених особистісних засад, які можуть не відповідати формальним соціальним законам і правилам.

Залежно від мети, соціальних і психологічних дистанцій, які виникають між студентами, виокремлюють кілька рівнів міжособистісного спілкування:

а) соціально-рольовий - мета спілкування - виконання очікуваної ролі, демонстрування знання норм соціального середовища;

б) діловий (маніпулятивний) - організація спільної діяльності, пошук засобів підвищення ефективності співробітництва тощо;

в) особистісний, мета - задоволення потреби в розумінні, співчутті, співпереживанні.

Сучасні американські психологи П. Вацлавік, Д. Бівін та Д. Джексон у праці «Прагматика людських комунікацій» визначили найважливіші особливості трансакційності міжособистісного спілкування [4, с. 72]:

1. Неуникність спілкування. Суть цього принципу в тому, що всі повинні комунікувати; комунікація не має свого протичлена «некомунікації». Навіть якщо особа не хоче спілкуватися 3 кимось, то все ж вона стає джерелом інформації для інших і в такий спосіб включається поза власною волею в усезагальну комунікацію.

2. Невідворотність спілкування. Цей принцип характеризується тим, що інформація повідомлень у спілкуванні творить нові ментальні стани тих, хто іiі сприймає, чи навіть нові ситуації. Невідворотність результатів спілкування відображена у прислів’і: «Слово не птах: випустиш - не впіймаєш».

3. Двоаспектність спілкування. Значеннєвий аспект спілкування передбачає 
описування осмисленого учасниками спілкування реального (чи такого, що вважається реальним) світу. Одночасно учасники описують існуючі між ними взаємозв'язки: соціально-рольові, психологічні, духовні тощо. Це аспект реляційний. Кожен вчинок стосовно іншої особи є інформаційним у тому сенсі, що окреслює і модифікує взаємозв'язки між цими особами.

4. Взаємопристосування учасників. Цей принцип вимагає узгодження систем знаків вербального i невербального кодів комунікантів, які можуть суттєво відрізнятись. Ідеться не лише про різні мови, а й про специфічне використання засобів мовного коду спільної для мовця й слухача ідіоетнічної мови (ідіостилі), зумовлене ними соціальними, віковими, статевими, культурним и та іншими чинниками.

5. Пунктуаційність подій. Сутність цього принципу полягає у внесенні кожним 3 учасників комунікації у спілкування свого бачення послідовності, упорядкованості подій, причин і наслідків, стимулів і реакцій тощо.

Тенденції розвитку сучасного спілкування істотно змінюються, що зумовлено впливом науково-технічного прогресу i науково-технічної революції. Однак, як зазначає Й. Стернін, найважливішою причиною цих змін є персоніфікація особистості студента $[5, \quad$ с. 52]. Персоніфікація особистості- усвідомлення людиною індивідуальної неповторності, несхожості на інших людей. Персоніфікація впливає на мобільність, культуру особистості, почуття власної гідності, духовні й матеріальні потреби. Із персоніфікацією пов'язані вибір цінностей, прийняття самостійних рішень; зменшується час, протягом якого людина спілкується з близькими їй людьми, але, відповідно, збільшується час комунікації з новими, часто чужими і неприємними людьми; зростає дистанція між поколіннями; збільшується кількість мікрогруп у колективах, кількість об'єднань студентів за груповими інтересами.

Персоніфікація особистості значною мірою позначається на спілкуванні, яке в сучасному навчальному процесі характеризується певними особливостями.

1. Розширюються сфери спілкування.

2. Збільшується питома вага коротких, поверхових мовленнєвих контактів;

3. Скорочується час спілкування зі студентами за рахунок зростання часу «спілкування» із засобами масової інформації.

4. Зростає рівень знеосіблення спілкування студентів, збільшується кількість ситуацій, у яких вони спілкуються, не знайомлячись, не вступаючи в особистісні стосунки; відбувається лише інформаційний обмін без налагодження духовних зв'язків.

5. Розширюється сфера застосування усного мовлення. Студенти все менше листуються, частіше спілкування відбувається по телефону, із застосуванням Інтернету тощо. Катастрофічно знижується культура писемного мовлення, погіршується грамотність.

6. Зростає частка спілкування за допомогою засобів сучасного зв’язку (факс, мобільний телефон, електронна пошта, Інтернет).

Дослідження різних аспектів навчальної комунікації виявило багато нових проблем, засвідчило необхідність виходу за межі мовного коду, хоч би як широко його тлумачили: як мовлення, компетенцію, вживання тощо [3, с. 77]. Спілкування за допомогою іноземної мови є різновидом навчальної діяльності загалом, у межах якої взаємодіють студенти 3 різними соціальними, психологічними, когнітивними, духовними особливостями, а також мовні засоби, конситуативні та інші чинники.

Серед значної кількості понять, упроваджених у лінгвістичний обіг комунікативним підходом, виокремлюють стиль спілкування, комунікативний регістр, 
тон (тональність) спілкування, атмосферу спілкування (комунікаціі), зрозумілість/незрозумілість мовлення, вдале/невдале спілкування та ін. У всіх цих поняттях переплетені лінгвальні й позалінгвальні елементи.

Термін «мовна особистість» отримує своє специфічне тлумачення. У науці він $є$ багатозначним. Дослідження проблеми мовної особистості, спроба типології $\epsilon$ актуальною, адже тривалий час учасників спілкування розглядали як ідеальні сутності, відтак як узагальнених носіїв соціальних, інколи психологічних ознак.

Мовна особистість - індивід, який володіє сукупністю здатностей i характеристик, які зумовлюють створення й сприйняття ним текстів, що вирізняються рівнем структурно-мовної складності таглибиною й точністю відображення дійсності. Вичерпної типології мовних особистостей ще не створено. Найприйнятнішою 3 них $\epsilon$ типологія Ю. Караулова. Він подає структуру мовних особистостей, організовану на трьох рівнях: вербально-семантичному, когнітивному та прагматичному. Вербальносемантичний рівень передбачає нормальне володіння природною мовою. Це «власне» мовна компетенція.

Когнітивний рівень охоплює інтелектуальну сферу особистості, даючи досліднику вихід через мову, процеси говоріння і розуміння - до знання, свідомості, процесів пізнання людини. Його «одиницями $є$ поняття, що виформовуються у кожної мовної індивідуальності в більш чи менш упорядковану, більш чи менш систематизовану «картину світу».

Прагматичний рівень охоплює мету, мотиви, інтереси, установки та інтенціональності. Цей рівень забезпечує в аналізі мовної особистості закономірний перехід від оцінювання іiі мовленнєвої діяльності до осмислення мовленнєвої діяльності. Лінгвіст-педагог Т. Дрідзе створила типологію мовних особистостей, виходячи із соціопсихологічної сутності людини і її втілення в тексті [2, с. 72]. За основу вона взяла систему зразків мовленнєвих виразів, їхні звукові особливості (мелодичні, динамічні, темпоральні, артикуляційні). Ураховуючи типологію вищої нервової діяльності, опрацьовану російським психологом І. Павловим, сучасний дослідник Я. Луп'ян проаналізував взаємозв'язок між типами акцентуації особистості та сукупністю характеристик поведінки (зокрема, мовленнєвої) людей (легкість встановлення контактів, особливості сімейного і службового спілкування, конфліктні ситуації). Російський мовознавець С. Сухих пропонує типологію комунікантів розглядати як структуру мовних особистостей: риси характеру, здібності, організовані певним чином під впливом темпераменту й установки, рівень володіння мовним кодом. Сучасний російський лінгвіст К. Сєдов акцентує на трьох типах мовних особистостей: конфліктному, центрованому, кооперативному.

Конфліктному типу притаманна установка на себе й одночасно проти партнера по комунікації. Його підтипами є конфліктно-агресивний (відкрита ворожість до партнера) i конфліктно маніпулятивний (вбачання в партнері лише об'єкта маніпуляціі).

Центрований тип характеризується установкою на себе, ігноруванням партнера по комунікації. Втілюється в активно-центрованому підтипі (перебиває партнера, намагається бути «головним») і пасивно-центрованому (неуважний у спілкуванні).

Кооперативний тип постійно демонструє увагу до партнера по комунікації, не забуваючи при цьому про себе. У його межах виокремлюють: кооперативнокомфортний підтип (демонструє згоду з позицією співбесідника) і кооперативноактуалізаторський (намагається стати на позиції співбесідника і подивитись на обговорюване його очима).

Сучасний американський лінгвіст Роберт Нортон пропонує кілька стилів 
спілкування: домінантний (постійне переважання співбесідника); драматичний (3 використанням драматичних ефектів); агресивний (вияв недружнього ставлення, бажання підкорити співбесідника); заспокійливий (3 використанням засобів заспокоєння); вражаючий (з використанням незвичних способів впливу на співбесідника); точний (оперування фактами); надихаючий (стимулюючий вплив на співбесідника); уважний (орієнтація на співбесідника); дружній (позитивне ставлення до співбесідника); відкритий (щире демонстрування намірів) [6, с. 37]. Стиль спілкування $\epsilon$ важливим складником формування тональності й атмосфери, у яких відбувається комунікація.

У дослідженнях останніх років усе частіше говорять про партнерський i непартнерський стилі спілкування. Партнерський стиль спілкування передбачає співробітництво у виробленні спільної позиції 3 питання, яке обговорюється. Партнера вислуховують, не перебиваючи, виважено оцінюють його судження i вчинки, не нав'язують йому рішень, намагаються донести до нього свою точку зору. Партнерський стиль може бути рівноправним і поступливим.

Непартнерський стиль спілкування полягає в ігноруванні одним із учасників комунікації точки зору співбесідника, негативному ставленні до теми бесіди, акцентуванні лише на власних проблемах; така особа створює напруженість, часто принижує партнера, нав'язує йому свої теми і проблеми, неуважно слухає, поспішає давати поради тощо.

Стиль спілкування яскраво виражений у професійній педагогічній сфері. У цьому контексті виокремлюють: авторитарний стиль (чітка мова; короткі розпорядження, вказівки; відсутність емоцій тощо); демократичний стиль (товариський тон розмови, інструкції у формі пропозицій, заохочення та покарання із порадами тощо). Психологи наголошують на важливості оптимального стилю спілкування, який передбачає відсутність егоцентричних установок, наявність інтересу до співбесідника, доброзичливе ставлення до нього, яке не заперечує вимогливості.

Отже, стаття рожезглядає мовні стратегії як механізми освоєння і користування іноземними мовами в багатомовному культурному просторі. Їх сукупність є основним культурним комунікаційним засобом, провідним елементом соціалізації особистості, iii аккультурації. Поряд і спираючись на досягнення таких наук, як семіотика (аналіз знакового представництва мови), лінгвістика (аналіз природних мов), культурна семантика (аналіз мови як засобу відображення смислу) філософія освіти розглядає мовні стратегії як засіб розуміння народами культурних відмінностей одне одного, осягнення цих відмінностей як унікального формовитвору єдиної людської сутності, досягнення на цій основі їх (особливостей) толерантного сприйняття. Вони розглядаються як засіб подолання непорозуміння (неадекватного розуміння), яке завжди виникає при комунікації культур у багатокультурному європейському просторі.

Опануання мовних стратегій $є$ пріоритетним напрямом освітньої політики країнучасників Болонського процесу. Отже, процес навчального спілкування, його атмосфера, тональність, кінцевий результат, успіх або невдача значною мірою залежать від комунікативної майстерності студентів. Важливий складник комунікативної майстерності - індивідуальний стиль спілкування, вироблення якого $€$ завданням навчального процесу та кожного студента - майбутнього вчителя.

\section{Література}

1. Першукова О. О. 3 історії розвитку соціокультурних аспектів вивчення іноземних мов у Європі / О. О. Першукова // Іноземні мови. - 1999. - № 4. - С. 16-20. 
2. Садохин А. П. Введение в теорию межкультурной коммуникации / А. П. Садохин. - $\quad$ М. : $\quad$ Высшая школа, 2005. - 310 с. 3. Сафонова В. В. Социокультурный подход к обучению иностранным языкам / В. В. Сафонова. - М. : Высшая школа, 2001. - 311 с. 4. Скубашевська Т. Мовні комунікації: суспільна потреба та ії реалізація / Т. Скубашевська // Нова парадигма. - 2005. - № 39. - С. 3539. 5. Коломінова О. О. Шляхи формуванння лінгвокраїнознавчої компетенції учнів початкової школи у процесі навчання англійської мови / О. О. Коломінова // Нариси досліджень у галузі гуманітарних наук у педвузі : зб. наук. та науково-метод. праць. Горлівка : ГДПІІМ, 2002. - С. 250-252. 6. Формування професійної культури вчителя в контексті інтеграції України в європейський освітній простір: Матеріали регіонального науково-практичного семінару / за ред. проф. Терещука Г. В. - Тернопіль : Вид-во ТНПУ ім. В. Гнатюка, 2007. - 177 с.

УДК 378.147(07)+371:811

Тетяна Мішеніна

\section{ФОРМУВАННЯ ПРЕДМЕТНОЇ КОМПЕТЕНТНОСТІ У МАЙБУТНІХ ФІЛОЛОГІВ ПЕДАГОГІЧНИХ ВИШІВ У ПРОЦЕСІ ВИВЧЕННЯ ЛАТИНИ}

Мішеніна Т. М. Формування предметної компетентності у майбутніх філологів педагогічних вишів у процесі вивчення латини.

У статті розроблено систему завдань, спрямованих на формування предметної компетентності майбутніх філологів у процесі навчання латини в педагогічних вишах. Принцип міжпредметності дозволяє вибудовувати предметно-орієнтовану стратегію навчання не тільки на основі власне психолого-педагогічної, філологічної підготовки студента-філолога, але й на основі міжпредметних блоків предметів знань, які характеризують його розумову діяльність у процесі розв'язання практичних завдань, пов'язаних із фаховою підготовкою.

Ключові слова: предметна компетентність, майбутні філологи, педагогічний виш, предметно-орієнтована підготовка.

Мишенина Т. М. Формирование предметной компетентности у будущих филологов педагогических вузов в процессе изучения латыни.

В статье разработана система заданий, направленных на формирование предметной компетентности будущих филологов в процессе изучения латыни в педагогических вузах. Принцип межпредметности позволяет выстраивать предметноориентированную стратегию обучения не только на основе собственно психологопедагогической, филологической подготовки студента-филолога, но и на основе межпредметных блоков предметов знаний, которые характеризируют его умственную деятельность в процессе решения практических заданий, связанных с профессиональной подготовкой.

Ключевые слова: предметная компетентность, будущие филологи, педагогический вуз, предметно-ориентированная подготовка.

Mishenina T. M. Formation of subject competence of future philologists of pedagogical universities in the study of Latin.

The paper developed a system of tasks aimed at the formation of the subject competence of future philologists in the process of studying Latin in pedagogical institutes. The principle of inter-disciplinary approach allows to build subject-oriented learning 